technical manner so as to emasculate the usefulness of the declaratory procedure.

Edward W. Rosston.

\title{
NEGLIGENCE PLEADING: ALLEGING DEFENDANT'S BREACH OF DUTY
}

\section{ALIEGING NEGLIGENCE GENERAILY}

In actions for negligence, plaintiff must aver: (1) facts showing a duty on defendant's part to protect plaintiff from the injury of whicl he complains; (2) defendant's failure to perform that duty; (3) proximate causation; and (4) damage to plaintiff. ${ }^{1}$ Defendant's duty to take reasonable care will ordinarily be inferred fron a statement of the relative positions of plaintiff and defendant before and at the time of the injury. ${ }^{2}$ A statement to the effect that "as the proximate result of defendant's negligence plaintiff suffered the injuries complained of" sufficiently alleges causation. ${ }^{3}$ Pleading damage involves the same considerations in negligence cases as in other types of actions. ${ }^{4}$

More difficulty arises as to alleging defendant's breach of duty, and it is to this problein that the present note is devoted. Where plaintiff has been run down by defendant's automobile, will the general allegation that defendant negligently operated his automobile be sufficient? Or unust plaintiff allege the specific acts of defendant's negligence which he hopes to prove, such as exceeding the speed limit,

1 Grosetti v. Sweasey (1917) 176 Cal. 793, 169 Pac. 687; Minter v. San Diego Consol. Gas Etc. Co. (1919) 180 Cal. 723, 182 Pac. 749; Miller v. Pacific Constructors, Inc. (1945) 68 Cal. App. (2d) 529, 157 P. (2d) 57; 19 CAL. JUR. 665, 38 Ax. JuR. 948.

2 Malloy v. Hibernia Sav. Etc. Soc. (1889) 3 Cal. Unrep. 76, 21 Pac. 525; Katz v. Helbing (1928) 205 Cal. 629, 271 Pac. 1062, (1929) 62 A. L. R. 825; McAllister v. Brown (1931) 114 Cal. App. 239, 299 Pac. 753; 19 CaL. JUR. 666; 45 C. J. 1061. However, "when the facts alleged show that plaintiff and defendant stand in such relation to each other that the defendant is not chargeable with negligence ... . unless unusual conditions coexist with the conditions alleged, such unusual conditions will not be presumed to exist ... but must be alleged." Shanley v. American Olive Co. (1921) 185 Cal. 552, 556, 197 Pac. 793,794 . Thus, where by the substantive law, plaintiff's recovery depends on his having been rightfully on defendant's land, a license or invitation from defendant must be averred. Schmidt v. Bauer (1889) 80 Cal. 565, 22 Pac. 256; Grundel v. Union Iron Works (1904) 141 Cal. 564, 75 Pac. 184; Herzog v. Hemphill (1907) 7 Cal. App. 116, 93 Pac. $899 ; 45$ C. J. 1053.

3 Guilliams v. Hollywood Hosp. (1941) 18 Cal. (2d) 97, 114 P. (2d) 1; Rannard v. Lockheed Aircraft Corp. (1945) $26 \mathrm{Cal}$. (2d) 149, 157 P. (2d) 1; Hamilton v. San Francisco Etc. Ry. (1920) 48 Cal. App. 761, 192 Pac. 323; Ades v. Brush (1944) $66 \mathrm{Cal}$. App. (2d) 436, 152 P. (2d) 519; Ciarz, Code Pleading (1928) 205. Cf. Kat $z$ v. Helbing, supra note 2 .

Treadwell v. Whittier (1889) so Cal. 574, 22 Pac. 266, 13 Am. St. Rep. 175, 5 L. R. A. 498; Samuels v. Calif. St. Etc. Ry. (1899) 124 Cal. 294, 56 Pac. 1115; Worden v. Central Fireproof Bldg. Co. (1916) 172 Cal. 94, 155 Pac. 839; Kuhns v. Marshall (1919) 44 Cal. App. 588, 186 Pac. 632; Latky v. Wolfe (1927) 85 Cal. App. 332, 259 Pac. $470 ; 45$ C. J. 1097. 
having improper brakes, or failing to keep a lookout? In order not to reveal all the facts of his case, to secure greater freedom at the trial, and often because he does not know the details of the accident and wishes to rely on the doctrine of res ipsa loquitur, ${ }^{5}$ plaintiff will attempt to state his cause as generally as possible; while defendant will seek to pin plaintiff down and discover the facts of his opponent's case by demanding the most specific statement possible.

At common law, the customary allegation of negligence was very general; the gist of the complaint was that "defendant so carelessly (negligently, unskillfully, etc.) drove his horse, that through his carelessness, his horse struck the plaintiff's horse and cart". " Despite the common code provision that "the complaint shall contain a plain and concise statement of the facts $", T$ which might seem to require greater particularity, nearly all code states have to some extent followed the common-law precedents here as in other instances. ${ }^{8}$ Thus, as against a general demurrer, objection to the introduction of any evidence, or motion for judgment on the pleadings, it is sufficient to allege that defendant negligently did some act, without specifymg the exact means or manner. ${ }^{9}$ California cases $^{10}$ and the Federal Rules of Civil Procedure ${ }^{11}$ are in accord. The reason for the rule is well expressed in a recent California case: ${ }^{12}$ "The standard of pleading in negligence cases rests upon considerations of fairness and convenience in view of the situation of the opposing parties, and the rule permitting the pleading of negligence in general terms finds justification in the fact

${ }^{5}$ See section III, infra.

6 Croft v. Alison (1821) 4 B. \& Ald. 590, 106 Eng. Rep. 1052; Moreton v. Hardern (1825) 4 B. \& C. 223, 107 Eng. Rep. 1042; Williams v. Holland (1833) 10 Bing. 113, 131 Eng. Rep. 848.

7 E.g., Cal. Code Crv. Proc. $\$ 426$.

8 Thus use of the common counts is permitted under the codes. King, Use of the Common Counts in California (1941) 14 So. CALrF. L. REv. 288. Great particularity is required for actions based on fraud, 12 CAL. JuR. 806 , while very general allegations will suffice in suits to quiet title, Ephraim v. Metropolitan Trust Co. (1946) 28 A. C. 859, 172 P. (2d) 501, and actions for conversion, Wendling Etc. Co. v. Glenwood Etc. Co. (1908) 153 Cal. 411,95 Pac. 1029.

938 AM. JUR. 951; 45 C.J. 1075, 1082 ; Notes (1903) 59 L. R. A. 209; (1943) 41 Mich. L. Rev. 760; (1941) 6 Mo. L. Rev. 512. Equivalent words may be used in place of "negligently". Fisher v. Western Fuse Etc. Co. (1910) 12 Cal. App. 739, 108 Pac. 659 ("heedless or reckless").

10 Stephenson v. Southern Pac. Co. (1894) 102 Cal. 143, 34 Pac. 618, 36 Pac. 407; Bergen v. Tulare County Power Co. (1916) 173 Cal. 709, 161 Pac. 269; Opitz v. Schenk (1918) $178 \mathrm{Cal}$. 636, 174 Pac. 40 (permitting introduction of evidence of violation of city ordimance) ; Dunn v. Dufficy (1924) 194 Cal. 383, 228 Pac. 1029; Barbieri v. Law (1930) 209 Cal. 429, 287 Pac. 464; Taylor v. Oakland Scavenger Co. (1938) $12 \mathrm{Cal}$. (2d) 310, 83 P. (2d) 948; Rannard v. Lockheed Aircraft Co., supra note 3; Roberts v. Griffith Co. (1929) 100 Cal. App. 456, 280 Pac. 199.

11 Sierocinski v. Du Pont Co. (C. C. A. 3d, 1939) 103 F. (2d) 843; (1940) 28 CALIF. L. Rev. 235; Form 9, Appendix of Forms, Fed. Rules Crv. Proc., 28 U.S. C. (1940) following \$723c.

12 Rannard v. Lockheed Aircraft Co., supra note 3, at 157, 157 P. (2d) at 5. 
that the person charged with negligence may ordinarily be assumed to possess at least equal, if not superior, knowledge of the affair to that possessed by the injured party."

It is thus a sufficient allegation of defendant's breach of duty in cases involving vehicles merely to plead that defendant negligently drove his automobile ${ }^{13}$ or negligently operated its train, ${ }^{14}$ and in malpractice cases to aver that certain treatment was negligently administered by defendant, without alleging in what respect it was deficient or improper. ${ }^{15}$ Examples of sufficient allegations in other situations are given in the note. ${ }^{16}$ But some act or omission, however broad or general, must be averred to have been negligently done; it will not suffice to say that due to defendant's negligence, plaintiff was injured. ${ }^{17}$

While it is well settled that a general allegation of negligence will withstand a general demurrer, there is considerably less certainty as

13 Wiley v. Cole (1921) 52 Cal. App. 617, 199 Pac. 550; Seney v. Pickwick Stages (1927) 82 Cal. App. 226, 255 Pac. 279; Queirolo v. Pac. G. \& E. Co. (1931) 114 Cal. App. 610, 300 Pac. 487.

14 Cunningham v. Los Angeles R. (1897) 115 Cal. 561, 47 Pac. 452; Stein v. United Railroads (1911) 159 Cal. 368, 113 Pac. 663.

15 Guilliams v. Hollywood Hosp., supra note 3; Criss v. Angelus Hosp. Assn. (1936) 13 Cal. App. (2d) 412, 56 P. (2d) 1274; Abos v. Martyn (1939) 31 Cal: App. (2d) 705, 88 P. (2d) 797; Smith v. Beauchamp (1945) 71 Cal. App. (2d) 250, 162 P. (2d) 662 ; Swan, California Law of Malpractice (1945) 33 Caldr. L. REv. 248. In Rannard v. Lockheed Aircraft Corp., supra note 3, allegations substantially as follows were held sufficient: (1) that defendant physician negligently conducted a physical examination; (2) that defendant employer negligently failed to employ a physician possessed of or capable of exercising that degree of skill, ability, or learning practiced by physicians practicing in the locality; (3) that defendant negligently advised plaintiff to undergo an operation for hernia.

10 Where plaintiff was injured in a falling elevator an allegation that "defendant neghigently failed to properly operate said elevator" was held sufficient. Champagne v. Hamburger \& Sons (1915) 169 Cal. 683, 147 Pac. 954. Where plaintiff's dwelling was damaged by the explosion of defendant's powder mill the following allegations were termed sufficient: that defendant carelessly, negligently, improvidently and unsafely maintained a powder magazine which was improperly constructed; that defendant employed a careless, heedless, and reckless servant well knowing his unfitness. Fisher v. Western Fuse Etc. Co., supra note 9.

Also held sufficient were allegations substantially as follows: that defendant negligently allowed gas to escape and ignite and burn plaintifi's home, Davidson v. Am. Liquid Gas Corp. (1939) 32 Cal. App. 382, 89 P. (2d) 1103; that a roof fell on plaintiff by reason of its imperfection, defectiveness, unsafety, and inadequacy of construction, Ingalls v. Monte Cristo Oil Etc. Co. (1917) 176 Cal. 128, 167 Pac. 857; that a winch and other appliances hy which plaintiff was injured were defective and insufficient, Lejeune v. Gen. Petrol. Corp. (1932) 128 Cal. App. 404, 18 P. (2d) 429; that plaintiff was injured by the negligence of the employees of defendant and each of them in operating a winch, ibid.; that defendant negligently maintained its power line so that the wires broke, Vertson v. Los Angeles (1931) 116 Cal. App. 114, 2 P. (2d) 411; that defendant neghigently permitted a malted milk served to plaintiff to contain a piece of cork, Smith v. McClary (1938) 28 Cal. App. (2d) 468, 82 P. (2d) 712.

17 See Cary v. Los Angeles Ry. Co. (1910) 157 Cal. 599, 603, 108 Pac. 682, 684, (1911) 21 Ann. Cas. 1329, 1330, 27 L. R. A. (N.s.) 764, 767; Guilliams v. Hollywood Fosp., supra note 3, at 101, 114 P. (2d) at 4; McGehee v. Schiffman (1906) 4 Cal. App. 50, 53, 87 Pac. 290; Ctark, Code Pleading (1928) 206; 45 C. J. 1078. 
to whether such a general allegation is subject to a motion to make more definite, a demand for a bill of particulars, or a special demurrer for uncertainty. ${ }^{18} \mathrm{~A}$ majority of jurisdictions appear to follow the rule that such objection may be successfully raised except where the facts are particularly within the knowledge of the defendant. ${ }^{10}$ The California cases are conflicting and do not appear to turn on whether or not the facts were within defendant's particular knowledge. However, the broad principle has been laid down in several cases not mvolving negligence pleading that a demurrer for uncertainty does not lie where the pleading shows a superior knowledge of the facts on the part of the demurring party. ${ }^{20}$

In Lang v. Lilley \& Thurston $\mathrm{Co}_{.}^{21}$ and McAllister v. Brown, ${ }^{22}$ defendant's general and special demurrers were sustained with leave to amend, and plaintiff declined to plead further. In short opinions citing little or no authority, ${ }^{23}$ judgments for defendant on the pleadings were affirmed on the ground that both demurrers were properly sustained since the complaints did not specify in what respect defendants were negligent. Three decisions contain dicta that a special demurrer should be sustained. ${ }^{24}$

Ten cases supporting the opposite view may be cited, but these, too, leave much to be desired in the way of a careful consideration of the problem. In two of these cases where general and special demurrers had been sustained without leave to amend, the dismissals were reversed on the ground that plaintiff's general allegations were not

18 The remedy in California, if any, is by special demurrer for uncertainty. McFarland v. Holcomb (1898) 123 Cal. 84, 55 Pac. 761; Butler v. Robinson (1926) 76 Cal. App. 223, 244 Pac. 162; CaL. Code Civ. Proc. $\$ 430$.

10 Note (1903) 59 L.R. A. 209; (1927) 16 CaLr. L. Rev. 151; 38 Air. Jur. 954; 45 C. J. 1080, 1084, and cases cited.

20 Schaake v. Eagle Etc. Can Co. (1902) 135 Cal. 472, 63 Pac. 1025, 67 Pac. 759; Swasey v. de L'Etanche (1936) 17 Cal. App. (2d) 713, 62 P. (2d) 753; Corum v. Hartford Acc. \& Ind. Co. (1945) 67 Cal. App. (2d) 891, 155 P. (2d) 710.

21 (1912) 20 Cal. App. 264, 128 Pac. 1031.

22 Supra note 2.

23 No authorities are cited in the McAllister case. The Lang case relies on language from Stephenson v. Southern Pac. Co., supre note 10, and similar cases, to the cffect that it is necessary "to specify the particular act or acts alleged to have been negligently done." While this language is ambiguous, in its original context it was addressed simply to the proposition that it is not sufficient to allege that through defendant's negligence plaintiff was injured, but that some act must be allowed.

The Lang and McAlhister cases, insofar as they require a high degree of particularity to withstand a general demurrer, were disapproved in Rannard,v. Lockheed Aircraft Corp., supra note 3.

24 Stephenson v. Southern Pac. Co., supra note 10, at 149, 34 Pac. at 620 (holding general allegation sufficient against general demurrer); Abos v. Martyn, supra note 15, at 708, 88 P. (2d) at 798 (same); Baisley v. Henry (1921) 55 Cal. App. 760, 764, 204 Pac. 399, 401 (complaint held insufficient on other grounds). 
obnoxious to either form of demurrer. ${ }^{25}$ In two other cases where such demurrers had been sustained with leave to amend and plaintiff declined to amend, judgment for defendant on the pleadings was reversed for the same reason..$^{26}$ In a number of cases, defendant's special demurrer has been overruled and trial had on the merits, resulting in judgment for plaintiff. Such judgments may be upheld without considering whether the overruling of the demurrer was erroneous, on the ground that even if erroneous, such error was not prejudicial. ${ }^{2 \pi}$ In three of these cases, however, affirmance was rested on the alternate grounds that the overruling of the special demurrer was proper, and that even if error it was not prejudicial. ${ }^{23}$ And three other decisions rest solely on the ground that the special demurrer was properly overruled. ${ }^{29}$

The recent case of Rannard v. Lockheed Aircraft ${ }^{30}$ (where only attack by general demurrer was involved) appears to leave the question open. While certain language in the McAllister and Lang cases ${ }^{31}$ requiring a high degree of particularity was disapproved, it was said that these cases might be distinguished on the ground that the complaint in each case was attacked by special as well as general demurrer.

\section{ALLEGING NEGLIGENCE SPECIFICALLY}

Under the codes, negligence may also be alleged specifically. The specific acts or omissions charged may be stated in separate counts ${ }^{32}$

25 Goldstein v. Healey (1921) 187 Cal. 206, 201 Pac. 462 ; Roberts v. Griffith Co, supra note 10 . This result is now reached on the ground that sustaining a special demurrer without leave to amend is an abuse of discretion, without discussing whether it would be error to sustain such demurrer with leave to amend. Guilliams v. Hollywood Hosp., sibpra note 3.

${ }^{26}$ Dunn v. Dufficy, supra note 10; Wiley v. Cole, supra note 13.

$2 \pi$ Even before the adoption of the doctrine of prejudicial error in 1914 (see Car. Const. art. VI, $\$ 41 / 2$; CAL. CoDE Crv. Proc. $\$ 475$ ), the same result was reached. Peters v. McKay (1902) 136 Cal. 73, 68 Pac. 478; Denms v. Crocker-Huffman Etc. Co. (1907) 6 Cal. App. 58, 91 Pac. 470 (error, if any, in overruling special demurrer not sufficiently substantial to demand reversal of a judgment on the merits).

28 Stein v. United Railroads, supra note 14 (judgment for plaintiff reversed on other grounds); Ingalls v. Monte Cristo Oil Etc. Co., supra note 16; Latky v. Wolfe, supra note 4 .

${ }^{29}$ Cunningham v. Los Angeles R., supra note 14 (judgment for plaintiff reversed on other grounds); Champagne v. Hamburger \& Sons, supra note 16; Saylor v. Taylor (1919) 42 Cal. App. 474, 183 Pac. 843.

30 Supra note 3. Without expressing its own opinion, the court quotes language from Abos v. Martyn, supra note 15, to the effect that a special demurrer should be sustained and language from Dunn v. Dufficy, supra note 10, to the opposite effect.

31 Supra notes 2 and 21, respectively.

32 Froeming v. Stockton Electric R. R. (1915) 171 Cal. 401 , 153 Pac. 712, Ann. Cas. 1918B 408; Potvin v. Pacific Greyhound Limes (1933) 130 Cal. App. 510, 20 P. (2d) 129; 45 C. J. 1036. Examples of specific pleadings are given in section IV, infra. 
or in a single count. ${ }^{33}$ And plaintiff will recover on sufficient proof of any well-pleaded allegation of negligence. ${ }^{34}$ In California, as in most jurisdictions, allegations of statutory and common-law negligence may be combined. ${ }^{35}$ Where the facts stated do not constitute a cause of action unless done negligently, it must be alleged that they were so done; but where from the facts alleged an inference of negligence arises, use of the term "negligently" or its equivalent is not essential. ${ }^{\text {"0 }}$

General and specific allegations may be combined in a single count $\mathrm{t}^{37}$ or stated in separate counts. ${ }^{38}$ By the majority rule, the specific will control the general, and the pleader will be confined in his proof to the particulars alleged. ${ }^{39}$ The California view, however, is that the plaintiff is not so confined unless the complaint clearly indicates the intention of the pleader to limit himself to such specific acts. ${ }^{40}$ Where general and specific allegations are combined in a single count, the complaint is insufficient if the specific acts alleged preclude the idea of defendant's negligence. ${ }^{41}$

33 Hoffman v. Tuolumne Water Co. (1858) 10 Cal. 413 ; Bergen v. Tulare County Power Co., supra note 10; Camozzi v. Colusa Sandstone Co. (1914) 26 Cal. App. 74, 147 Pac. 107; Bourguignon v. Peninsular Ry. (1919) 40 Cal. App. 689, 181 Pac. 669; Note (1913) 28 Ann. Cas. 101 ; 45 C. J. 1086.

34 Bergen v. Tulare County Power Co., supra note 10; Potvin v. Pacific Greyhound Lines, supra note 32.

35 Coleman v. Oakland (1930) 110 Cal. App. 715, 295 Pac. 59; see cases cited 45 C. J. 1087.

36 Silveira v. Iverson (1899) 125 Cal. 266, 57 Pac. 996; Herrick v. Oakland Motor Co. (1916) 29 Cal. App. 414, 155 Pac. 1006; South v. County of San Benito (1919) 40 Cal. App. 13, 180 Pac. 354; White v. Covell (1924) 66 Cal. App. 732, 227 Pac. 196; Lindberg v. Pantoleon (1929) 97 Cal. App. 112, 274 Pac. 1009.

37 Mudrick v. Market St. Ry. (1938) 11 Cal. (2d) 724, 81 P. (2d) 950, (1939) 118 A. L. R. 533 ; Radisich v. Franco-Itahan Packing Co. (1945) 68 Cal. App. (2d) 825, 158 P. (2d) 435 .

It has been held, under the federal rules, that where general and specific allegations of negligence are combined, the specific allegations will be stricken on motion as unnecessary. Hardin v. Interstate Motor Freight System (S. D. Ohio 1939) 26 Fed. Supp. 97; see Wild v. Knudsen (E. D. Tenn. 1941) 1 Fed. Rules Dec. 646, 647.

38 Ellis v. Jewett (1937) 18 Cal. App. (2d) 629, 64 P. (2d) 432 ; Snyder v. Wheeling Electrical Co. (1897) 43 W. Va. 661, 28 S. E. 733, 64 Am. St. Rep. 922.

39 Couch's Adm'r v. Black (1945) $301 \mathrm{Ky} .24$, 190 S. W. (2d) 681; Cherry v.'Dealers Transport Co. (E.D.Mo. 1946) 64 F. Supp. 682; 38 AM. Jur. 955; 45 C. J. 1084; Note (1903) 59 L. R.A. 209.

40 Olcese v. Hardy (1919) 40 Cal. App. 323, 180 Pac. 666; Jackson v. Hardy (1945) 70 Cal. App. (2d) 6, 160 P. (2d) 161. An intent so to himit a general allegation will be found in such an averment as: "defendant was guilty of willful misconduct as follows; to wit, driving at an excessive rate of speed." Ellis v. Jewett, supra note 38.

11 Thus where plaintiff accused one defendant of general negligence in failing to observe that the road on which he was transporting plaintiff terminated abruptly at the edge of a precipice and in the same count averred that no light or other warnings had been placed near the end of the road, the complaint was held insufficient to state a cause of action against that defendant. South v. French (1919) 40 Cal. App. 28, 180 Pac. 357. Accord: Denman v. Pasadena (1929) 101 Cal. App. 769, 282 Pac. 820. 


\section{THE EFFECT OF PLEADING ON RES IPSA LOQUITUR}

Important questions arise as to the effect of the form of pleading on plaintiff's right to rely on the doctrine of res ipsa loquitur. ${ }^{42}$ Where there are only general allegations of negligence and the case is otherwise a proper one, it is clear that plaintiff may rely on the doctrine. ${ }^{43}$ In such a case, introduction of evidence tending to show negligence in a particular respect does not prevent plaintiff's reliance on the doctrine $^{44}$ unless his proof as a matter of law leaves no room for the inference of negligence. 45 "There is no reason why proof of specific acts of negligence should wholly dispel the inference any more than it would in any other case. ... [Any other rule would penalize plaintiff] for going forward and making as specific a case of negligence as possible. ... he should be encouraged to prove as much as possible." 46

Where there is no general allegation and only specific acts of negligence are averred, the majority of California cases hold the maxim of res ipsa loquitur completely inapplicable. ${ }^{4 \pi} \mathrm{A}$ few cases, however, hold that the doctrine is available in such a situation. ${ }^{48}$ Two reasons are given for the first rule: that it cannot be said in view of the pleadings that defendant is in a better position than plaintiff to explam the

42 On res ipsa loquitur generally, see Carpenter, The Doctrine of Res Ipsa Loquitur in California (1937) 10 So. CarIF. L. REv. 166, and the ensuing discussion with Professor Prosser (1937) 10 ibid. 459 and 467; Goldin, The Doctrine of Res Ipsa Loquitur in Aviation Law (1945) 18 ibid. 15, 124; Shain, Res Ipsa Loquitur (1944) 17 ibid. 187; Note (1924) 12 CALIF. L. REv. 138. On the pleading problems involved, see Niles, Pleading Res Ipsa Loquitur (1929) 7 N. Y. U. L. Q. Rev. 415; Notes (1925) 13 CAIIF. L. Rev. 424; (1933) 31 MICE. L. Rev. 817; (1936) 14 Tex. L. Rev. 277; (1937) 11 U. of CIN. L. Rev. 375 ; (1933) 7 WASH. L. REV. 422.

43 Ales v. Ryan (1936) 8 Cal. (2d) 82, 64 P. (2d) 409; Kilgore v. Brown (1928) 90 Cal. App. 555, 266 Pac. 297 ; Queirolo v. Pac. G. \& E. Co., supra note 13; Vertson v. Los Angeles, supra note 16; Armstrong v. Wallace (1935) 8 Cal. App. (2d) 429, $47 \mathrm{P}$. (2d) 740; Mintzer v. Wilson (1937) 21 Cal. App. (2d) 85, 68 P. (2d) 370; Healey v. Market St. Ry. (1940) 41 Cal. App. (2d) 733, 107 P. (2d) 488.

44 Mansfield v. Pickwick Stages, Northern Div. (1924) 68 Cal. App. 507, 229 Pac. 890; Seney v. Pickwick Stages, supra note 13; Kilgore v. Brown, supra note 43; Strock v. Pickwick Stages System (1930) 107 Cal. App. 298, 290 Pac. 482; Armstrong v. Pac. Greyhound Lines (1946) 74 Cal. App. (2d) $367,168 \mathrm{P}$. (2d) 457 . This is said to be the nearly universal rule. See Note (1934) 93 A. L. R. 609.

45 Gritsch v. Pickwick Stages Systen (1933) 131 Cal. App. 774, 22 P. (2d) 554; Jorgensen v. East Bay Transit Co. (1941) 46 Cal. App. (2d) 189, 115 P. (2d) 556; Prosser, TORTs (1941) 306. On the dispelling of presumptions in general see Engstrom v. Auburn Auto. Sales Corp. (1938) 11 Cal. (2d) 64, 77 P. (2d) 1059; Blank v. Coffin (1942) 20 Cal. (2d) 457, 126 P. (2d) 868.

46 Leet v. Union Pacific R. R. Co. (1944) 25 Cal. (2d) 605, 621; 155 P. (2d) 42, 50; 158 A. L. R. $1008,1020$.

47 McKeon v. Lissner (1924) $193 \mathrm{Cal} .297,223 \mathrm{Pac} .965$; Harker v. So. Calif. Edison Co. (1927) 83 Cal. App. 204, 256 Pac. 848; Ingledue v. Davidson (1929) 102 Cal. App. 697, 283 Pac. 837; Smith v. McClary, supra note 16.

48 Lippert v. Pac. Sugar Corp. (1917) 33 Cal. App. 198, 164 Pac. 810; Soto v. Spring Valley Water Co. (1918) 39 Cal. App. 187, 178 Pac. 305. Cf. Chauvin v. Krupin (1935) 4 Cal. App. (2d) 322, 40 P. (2d) 904. 
accident $t^{49}$ and that permitting the application of the doctrine would be the equivalent of allowing plaintiff to prove a cause outside the scope of his pleading. ${ }^{50}$ The first reason is disapproved in a dictum in Leet v. Union Pacific Railroad Co. ${ }^{51}$ but no fault is found with the second. More consistent with the philosophy and reasoning of the Leet case than either of the above-mentioned rules is a third, also supported by some California authority ${ }^{52}$ This group of cases holds that res ipsa loquitur is applicable only as to the particular acts of negligence charged, and that to meet plaintiff's prima facie case, defendant, instead of negativing every possible ground of negligence, need only disprove his negligence as to those particulars alleged. Cases supporting each of the three rules may be found in other jurisdictions. ${ }^{63}$

Where negligence is averred generally and specifically in separate counts, res ipsa loquitur is apparently applicable to its full extent in California. ${ }^{54}$ But conflicting views exist both in California and elsewhere as to the result of alleging negligence both specifically and generally in a single count. ${ }^{55}$ One group of cases, typified by Gish v. Los Angeles Railway Corporation, ${ }^{56}$ holds the doctrine applicable only as to the acts and omissions alleged, and defendant need only rebut the inference of his negligence as to the acts alleged. In 1944, in a wellconsidered dictum, ${ }^{57}$ the state supreme court reviewed and cited the

49 Connor v. Atchison Etc. Ry. Co. (1922) 189 Cal. 1, 207 Pac. 378, 22 A. L. R. 1462 ; Jianou v. Pickwick Stages System (1931) 111 Cal. App. 754, 296 Pac. 108; Porter v. Rasmussen (1932) 127 Cal. App. 405, 15 P. (2d) 888; Smith v. McClary, supra note 16.

50 Marovich v. Central Calif. Traction Co. (1923) 191 Cal. 295, 216 Pac. 595; Atkinson v. United R. R. (1925) 71 Cal. App. 82, 234 Pac. 863.

51 Supra note 46 , at 619,155 P. (2d) at 49.

52 Phillips v. So. Calif. Edison Co. (1937) 23 Cal. App. (2d) 222, 72 P. (2d) 769; Wills v. Price (1938) 26 Cal. App. (2d) 338, 79 P. (2d) 406. Deserving especial attention is Chauvin v. Krupin, supra note 48 . Plaintiff was injured in a beauty parlor while her hair was being waved. She charged defendants specifically of negligently adjusting the heater to her head, negligently using and manipulating the heater, and failing to guard plaintiff sufficiently against contact therewith. Althougl there was no general allegation of negligence, the doctrine of res ipse loquitur was lield fully applicable since the acts specifically alleged constituted the entire operation by defendants in which plaintiff might have received her injuries.

53 See Notes (1932) 79 A. L. R. 48; (1925) 13 CALTr. L. REv. 424; (1910) 24 L. R. A. (N.S.) 788; L. R.A. 1915F 992; 38 AMr. JUR. 1001.

54 Ellis v. Jewett, supra note 38 .

55 Authorities cited in note 53 , stipra.

56 (1939) 13 Cal. (2d) 570, 90 P. (2d) 792. Accord: Sency v. Pickwick Stages, supre note 13; Atkinson v. United R. R., supra note 50. See Mintzer v. Wilson, supra note 43, at $89,68 \mathrm{P} .(2 \mathrm{~d})$ at 372 .

${ }^{57}$ Leet v. Union Pacific R. R., supra note 46 , at 617,155 P. (2d) at 49. Accord: McComas v. Al G. Barnes Shows (1932) 215 Cal. 685, 12 P. (2d) 630; Mudrick v. Market St. Ry., supra note 37; Roberts v. Sierra Ry. (1910) 14 Cal. App. 180, 111 Pac. 519, 527; Bourguignon v. Peninsular Ry., stepra note 33; Hackley v. Southern Pac. Co. (1935) 6 Cal. App. (2d) 611, 45 P. (2d) 447; McCole v. Merchants Express Corp. (1937) 19 Cal. App. (2d) 149, 64 P. (2d) 1130; Radisich v. Franco-Italian Packing Co., supra note 37. See Burke v. Dillingliam (1927) 84 Cal. App. 736, 739, 258 Pac. 627, 629. But see Roselip v. Raisch (1946) 73 Cal. App. (2d) 125, 134, 166 P. (2d) 340, 345. 
various lines of cases and espoused the broader rule that where there are general and specific allegations of negligence, plaintiff may rely on the doctrine to its full extent. "[D] efendant is advised by the pleading that he inust meet an inference of negligence (res ipsa loquitur) whatever may be the particular acts or omissions charged; that is, he has notice that he must be prepared to meet an inference of negligence which may embrace misconduct in addition to the specific instances alleged." 58

\section{WHAT IS A GENERAI ALLEGATION OF NEGLIGENCE?}

In jurisdictions holding that a specific pleading will prevent or limit the application of res ipsa loquitur and in those holding that a general allegation is subject to a motion to make more specific or to a special demurrer, it must often be determined whether a given pleading is general or specific. Little analysis seems to have been given the problem by courts or writers..$^{59}$ The test enunciated by California courts is: Does the pleading set out or attempt to explain the real underlying cause of the accident. ${ }^{60}$

An allegation that the vehicle, piece of machinery, or other object which made contact with plaintiff's person or property or otherwise directly caused him injury was "defective", "improperly constructed", "negligently operated" or "negligently maintained" will be considered general. Thus an averment that defendant negligently operated its locomotive and train is a general allegation of negligence. ${ }^{61}$

In Califorma at least, an allegation that a part of the object directly causing the injury was negligently maintained, constructed or operated will probably be held specific even where no further details of the alleged negligence are given. Thus when plaintiff was injured in a train wreck and alleged that the track was "uneven and unsafe", his pleading was declared specific. ${ }^{62}$

58 Leet v. Union Pacific R. R., supra note 46, at 618,155 P. (2d) at 49.

69 See Notes (1932) 79 A. L. R. 48; (1928) 40 U. of Mo. BULL. L. SER. 41. The Missouri courts seem to have heen most frequently concerned with the problem; over half of the cases in point found in the American Digest systein are from that jurisdiction.

60 Gish v. Los Angeles Ry. Corp., supra note 56; Lejeune v. Gen. Petrol. Corp., supra note 16; Radisich v. Franco-Italian Packing Co., sutpra note 37.

61 Roberts v. Sierra Ry., supra note 57. Accord: Vertson v. Los Angeles (negligently maintaining power line); Lejeune v. Gen. Petrol. Corp. (winch alleged to be defective), both supra note 16; Armstrong v. Wallace (negligently leaving sponge in plaintiff's abdomen); Mintzer v. Wilson (faulty construction of ceiling which had fallen on plaintiff), both supra note 43 . But in Smith v. McClary, supra note 16, an allegation that defendants negligently caused and permitted a malted milk served to plaintiff to contain a piece of cork, was held specific.

Similarly, an allegation that defendant's entire course of action was neghigent will be considered general, as when it is alleged that defendant negligently administered certain medical treatment. See cases cited in note 15, supra.

62 Marovich v. Central Calif. T. Co., supra note 50. Accord: Harker v. So. Calif. Edison, supra note 47 (alleging improper fuses when plaintiff's property was destroyed 
An allegation of the particular means or manner in which the vehicle or piece of machinery was negligently operated, constructed or maintained will be held specific. Thus allegations that a streetcar was overcrowded, ${ }^{63}$ was operated at an improper speed, ${ }^{64}$ or was operated without warning of its approach ${ }^{65}$ are specific. The use of a term only slightly less general than "operated", "maintained" or "constructed" may result in a pleading's being declared specific. Thus an allegation that defendant negligently "started" or "stopped" its streetcar with a jolt has been held specific. ${ }^{68}$ Where the particular part of the object causing the injury is declared to have been negligently operated or maintained in a specified manner, the pleading is more clearly specific, as allegations that defendant railroad permitted its track to become obstructed ${ }^{67}$ or (where a short circuit caused damage) that defendant's transformers were insufficiently grounded. ${ }^{\text {ss }}$

As we have seen, an allegation that defendant railroad negligently operated its train is clearly general. But it has been held that where defendant's particular negligent servant is pointed out (as when it is alleged that defendant's motorman negligently operated its streetcar), the allegation is specific. " Even an allegation that "the employees in

by a short circuit in defendant's power line); Beave v. St. Louis Transit Co. (1908) 212 Mo. 331, 111 S.W. 52 (negligently naintaining car, brakes and running gear). Contra: Dowdy v. Soutlern Traction Co. (Tex. Comm. of App. 1920) 219 S. W. 1092 (negligent building, erection and maintenance of track, roadbed and bridges and negligent operation of car, held general); MacDonald v. Metropolitan St. Ry. Co. (1909) 219 Mo. 468, 118 S. W. 78, 16 Ann. Cas. 810 (negligent and careless condition of appliances for going around curves held general).

In Ales v. Ryan, supra note 43, the complaint alleged: "That said operation was negligently, carelessly and recklessly performed by said defendants ... .; that such negligence, carelessness and recklessness consisted in this; that they negligently, carelessly and recklessly left within the abdomen of said [decedent] . . . a large laparotomy sponge, and that after the gall bladder of said [decedent] ... was removed, the incision made therefor was sewed up without removing said sponge." Brief for Respondents, p. 21, Ales v. Ryan (1935) 82 Cal. App. Dec. 397,47 P. (2d) 771. This was held a general allegation of negligence. Judgment for defendant was reversed on the ground that the trial court had erroneously excluded from the jury's consideration evidence that the sponges used were not equipped with rings or other safety devices. Cf. Carnahan v. Motor Transit Co. (1924) 65 Cal. App. 402, 224 Pac. 143, relied on by the court in the Ales case.

63 Mudrick v. Market St. Ry., supra note 37.

64 Ellis v. Jewett, supra note 38 ; Atkinson v. United R. R., suppra note 50; Sullivan v. Capital Traction Co. (1910) 34 App. D. C. 358. Cf. Hart v. Roth (1920) 186 Ky. 535, 217 S. W. 893 (averments of driving automobile rapidly and failing to give warning held general).

${ }^{65}$ Atkinson v. United R. R., supra note 50. In Lippert v. Pac. Sugar Corp., supra note 48 , an allegation that defendants increased the steam pressure to seventy pounds per square inch where the machinery was built to operate at a pressure of forty pounds per square inch, was held specific.

66 Gisl v. Los Angeles Ry Corp., supra note 56; Grimm v. Globe Printing Co. (Mo. 1921) 232 S. W. 676 (elevator). Cf. Ales v. Ryan, discussed supra note 62.

Gr Roberts v. Sierra Ry., supra note 57.

68 Harker v. So. Calif. Edison Co., supra note 47.

69 Miller v. United R. Etc. Co. (1911) 155 Mo. App. 528, 134 S. W. 1045 ; Mendenhall v. Springfield Traction Co. (Mo.App. 1930) $26 \mathrm{~S}$. W. (2d) 50. 
charge" negligently operated defendant's train has been held specific. ${ }^{70}$ California cases seem not to have applied this line of reasoning, having held that "negligent operation of the truck by defendant's driver" alleges negligence generally.

The same allegation may be general in one instance and specific in another. If plaintiff is injured in the wreck of a train, an allegation that defendant negligently constructed or maintained its trestle may be considered specific, ${ }^{72}$ yet if defendant is injured by the collapse of the trestle while he is walking over it, the same allegation would seem to be as general as plaintiff can make it.

While particularizing even slightly as to the manner, means or cause of an accident will make a pleading specific, ${ }^{73}$ particularizing as to the effect or result would not seem to make an otherwise general allegation specific. ${ }^{74}$ Thus an allegation that defendant negligently operated its streetcar so as to collide with another car belonging to defendant would appear to be as general with the italicized phrase as without it. ${ }^{\text {is }}$

Gish v. Los Angeles Railway Corporation ${ }^{\text {ib }}$ seems to be a unique aberration. The court somehow found both general and specific allegations in the following: "defendant ... negligently, carelessly, and recklessly stopped said car with a tremendous jolt and shock". If the decision stands for the proposition that the addition of the word "negligently" or its equivalent will render an otherwise specific allegation both specific and general, it stands alone. Having thus found

70 Ft. Worth \& R. G. Ry. Co. v. Neal (Tex. Civ. App. 1911) 140 S. W. 398. The majority view is clearly contrc. Southern Pac. Co. v. Hanlon (C. C. A.9th, 1925) 9 F. (2d) 294; Birmingham Ry. Etc. Co. v. Haggard (1908) 155 Ala. 343, 46 So. 519; Central of Ga. R. R. Co. v. Robertson (1919) 203 Ala. 358, 83 So. 102; West Chicago St. Ry. v. Mileham (1908) 138 Ill. App. 569; Harding v. Kansas City Pub. Service Co. (Mo. App. 1945) 188 S. W. (2d) 60; Hoeller v. St. Louis Pub. Service Co. (Mo. App. 1947) 199 S. W. (2d) 7; Russell v. Seattle R. \& S. Ry. (1907) 47 Wash. 500, 92 Pac. 288.

71 Seney v. Pickwick Stages; Queirolo v. Pac. G. \& E. Co., both supra note 13.

72 Mayfield v. St. Louis-San Francisco Ry. (Mo. App. 1925) 272 S. W. 1051.

73 Wills v. Price, supra note 52 (holding specific an allegation that as a result of vibrations from walking, a roll of linoleum in a furniture store fell on plaintiff).

74 Thus Missouri can consistently hold general an allegation that defendants so neghigently operated its train as to cause it suddenly to jerk, Rhodes v. Mo. Pac. R. R. Co. (1923) 213 Mo. App. 515, 255 S. W. 1084, and hold specific an allegation that defendant neghigently started its car with a jerk, Dieterman v. Springfield Traction Co. (Mo. App. 1930) 26 S. W. (2d) 866.

75 Compare the following: Davidson v. St. Louis Transit Co. (1908) $211 \mathrm{Mo} .320$, 109 S. W. 583 (held specific); Price v. Metropolitan St. Ry. (1909) 220 Mo. 435, 119 S. W. 932, 132 Am. St. Rep. 588 (disapproving the Davidson case and holding the allegation general) ; Hennekes v. Beetz (1920) 203 Mo. App. 63, 217 S. W. 533 (holding a similar allegation specific). Similar allegations were held general in: Chicago Union Traction Co. v. Mee (1907) $136 \mathrm{Ill}$. App. 98; Burdette v. Chicago Auditorium Assn. (1911) 166 Ill. App. 186; Imdley v. Sink (1940) 218 Ind. 1, 30 N. E. (2d) 456; Russell v. Seattle R. \& S. Ry., supra note 70.

70 Supra note 56. 
both general and specific averments, the court purported to follow the rule that such combination limits the applicability of res ipsa loquitur. Yet it held, in effect, that the pleading, though specific, was not so specific as to deprive plaintiff of any part of his reliance on res ipsa loquitur. This introduction of degrees of specificity only further obscures the already nebulous distinction between general and specific allegations.

\section{PLEADING GROSS NEGLIGENCE AND WILLFUL MISCONDUCT}

Considerable confusion exists in California as elsewhere as to the requirements for an allegation of gross negligence or willful misconduct. ${ }^{\pi T}$ In Malone v. Clemore ${ }^{\text {is }}$ the court said by way of dictum that a general allegation of ordinary negligence was sufficient, despite a con. curring opinion to the contrary in an earlier case. ${ }^{79}$ In Nichols $v$. $S m i t h^{80}$ a general allegation of ordinary negligence was held not to state a cause of action for gross negligence, although other grounds for reversal were also relied on by the court. The Nichols case was misinterpreted in Bartlett v. Jackson ${ }^{81}$ as holding a general allegation of gross negligence insufficient, and it was held in the latter case that an allegation that defendant was guilty of willful misconduct in the operation of an automobile was insufficient as against general and special demurrers. ${ }^{82}$ In a later case, ${ }^{83}$ an allegation that defendant "drove his automobile with intent that harm should result" was held sufficient to meet the requirement laid down in the Bartlett case that the particular act constituting the misconduct be specified.

Here the form of pleading cannot affect the applicability of res ipsa loquitur since that doctrine is inapplicable to infer gross negliligence or willful misconduct. ${ }^{84}$

i7 38 Axr. Jor. 958; 45 C. J. 1090; Notes (1905) 69 L. R.A. 601. On gross negligence and willful misconduct generally, see ProssER, TorTs (1941) 260, 402, 634; (1937) 37 Col. L. Rev. 671; (1937) 10 So. CaIIF. L. Rev. 515; Note (1944) 92 U. of PA. L. . REv. 431 ; 38 AMr. JUR. 958. While earlier forms of the California Guest Statute required only gross negligence, the present form requires intoxication or willful misconduct. CAL. VEH. CODE $\$ 403$.

78 (1931) 111 Cal. App. 13, 19, 295 Pac. 70, 72. (The complaint charged defendant with gross neghigence and listed the acts relied on.) In Castro v. Singh (1933) $131 \mathrm{Cal}$. App. 106, 21 P. (2d) 169, allegations of specific acts of defendant as being negligent were held to state a cause of action under a guest statute requiring gross negligence.

70 Michalitschke v. Wells, Fargo \& Co. (1897) 118 Cal. 683, 691, 50 Pac. 847, 849. (The majority opinion did not consider the question.)

80 (1934) 136 Cal. App. 272, 28 P. (2d) 693.

81(1936) 13 Cal. App. (2d) 435, 56 P. (2d) 1298.

82 In Kauffman v. Machin Shirt Co. (1914) 167 Cal. 507, 508, 140 Pac. 15, 16, it was stated that willfnl or wanton conduct must be pleaded, but no indication was given of the particularity required.

83 Frisvold v. Leahy (1936) 15 Cal. App. (2d) 752, 60 P. (2d) 151.

84 Lincoln v. Quick (1933) 133 Cal. App. 433, 24 P. (2d) 245. 
VI. CONCLUSIONS: THE APPROACH OF THE FEDERAI RULES

Under the present majority rule, as we have seen, plaintiff must allege negligence specifically if defendant interposes an objection for uncertainty, unless the plaintiff can show that the facts are particularly within defendant's knowledge. ${ }^{85}$ It would seem preferable, however, to shift the burden to defendant, requiring specific allegations only when defendant can show that the facts are not within his knowledge and can convince the court that he actually needs the information requested to prepare his defense. ${ }^{86}$

Yet even so modified, this rule presents serious drawbacks. It is often difficult to determine from the pleadings alone whether the facts are within defendant's particular knowledge or whether the pleading attacked is actually general or specific. Furthermore, whenever plaintiff is required to plead specifically, he can incorporate long and detailed allegations covering all possible specific acts of negligence and will recover if any one of his allegations is proved. ${ }^{85}$ The parties and the court will be confronted with a prolix and confusing complaint, and defendant will have been given no clearer idea of what plaintiff's proof will comprise.

On the other hand, the alternative rule, holding a general allegation sufficient under all circumstances as against an objection for uncertainty, is scarcely more palatable. In many instances defendant, in order properly to prepare his defense, needs more than a mere general allegation of negligence. Thus, as long as the pleadings are the primary means of fact revelation, it does not seem possible to formulate a rule that in all instances will operate with complete fairness toward both plaintiff and defendant.

An entirely different approach is exemplified in the Federal Rules of Civil Procedure. There, "the pre-trial functions of notice-giving, issue-formulation and fact-revelation ... [are no longer] performed primarily and inadequately by the pleadings .... The new rules ... restrict the pleadings to the task of general notice-giving. . . ."ss Plaintiff may thus allege negligence (as well as most other causes of

85 Authorities cited in note 19, supra. It has been suggested that plaintiff should not be required to allege specifically if res ipsa loquitur is applicable, but that where he cannot rely on that doctrine, specific allegations should be required since plaintiff will have to prove at least one such act in order to recover. See Shain, Res Ipsa Loquitur (1944) 17 So. CALIF. L. REv. 187, at 231. But it would seem difficult in many cases to determine from the pleadings alone whether res ipsa loquitur is applicable.

86 See Note (1923) 32 YAIE L. J. 483.

87 Froeming v. Stockton Electric R. R., supra note 32 ; Bergen v. Tulare County Power Co., supra note 10. However, if plaintiff alleges such acts as concurrent causes of his injury he may have to prove them all, Wormsdorf v. Detroit City Ry. (1889) 75 Mich. 472, 42 N. W. 1000, 13 Am. St. Rep. 453.

88 Hickman v. Taylor (1947) 329 U. S. 495, 500. 